\title{
Osseointegration Problem
}

National Cancer Institute

\section{Source}

National Cancer Institute. Osseointegration Problem. NCI Thesaurus. Code C62886.

Problem associated with interconnection between the bone tissue and the implanted device. 